\title{
Potential for Biomass and Biofuel through Sustainable Intensification of Agriculture and Reduction of Food Losses and Waste
}

\author{
Jeffrey Skeer ${ }^{1}$, Shunichi Nakada ${ }^{2}$ \\ ${ }^{1}$ IRENA Innovation and Technology Centre, Bonn, Germany \\ ${ }^{2}$ Japan International Research Center for Agricultural Science, Tokyo, Japan \\ Email: jskeer@irena.org, snakada@affrc.go.jp
}

Received 20 November 2015; accepted 11 January 2016; published 14 January 2016

Copyright (C) 2016 by authors and Scientific Research Publishing Inc.

This work is licensed under the Creative Commons Attribution International License (CC BY). http://creativecommons.org/licenses/by/4.0/

c) (i) Open Access

\begin{abstract}
Substantial potential exists to expand supplies of biomass for energy applications through more systematic collection of agricultural residues, more intensive cultivation of croplands, and reduced waste and losses in the food chain. This study aims to show how the potential can be calculated from public information sources, to put the potential in the context of global needs for liquid transport fuels, and to suggest some practical policy options for bringing part of the potential to market. It finds that if the theoretical potential is fully realized, enough liquid biofuel could be produced to displace the equivalent of all current global liquid fuel use for transport.
\end{abstract}

Keywords

Biomass, Biofuel, Sustainable, Yields, Food

\section{Introduction}

Substantial potential exists to expand both food and fuel supply in a sustainable fashion. While food and fuel production have often been seen as being in conflict, and while expanded biofuel production has been seen as leading to land use change that reduces global sequestration of carbon, there are actually several ways to boost food and fuel production simultaneously without using additional land. This study explores how much bioenergy could be produced in these ways, including through more systematic collection of agricultural residues, more intensive cultivation of croplands (with higher yields), and reduced waste and losses in the food chain.

As food production expands to meet the nutritional needs of growing populations, there is also increased production of agricultural residues. If sustainable shares of these residues were fully collected while allowing for 
residues that are fed to animals for meat and dairy production, substantial amounts would be left over. These could provide fuel for combined heat and power plants, process heat for first-generation biofuel production, or lignocellulosic feedstock for second-generation biofuel processes.

Accelerating yield growth through modern agricultural practices, it should also be possible to grow the same amount of food on less land. The freed up land could be planted with a mix of rapidly growing trees (short rotation coppice) for combined heat and power or second-generation biofuel, high-yielding conventional biofuel crops such as sugar cane, and grasses for lignocellulosic conversion.

Farmland needed for food production could be further reduced by managing the food chain more efficiently and by modifying food consumption habits. Globally, over a third of all food is lost or wasted. If food losses and waste could be reduced or eliminated, obviating the need to grow this food, substantial further amounts of land could be made available for bioenergy and biofuel production.

\section{Potential for Bioenergy from Sustainable Collection of Agricultural Residues}

For every ton of crop produced, an amount of residues is available in the field after harvest, of which a fraction can be practically and sustainably collected, typically assumed to be between a quarter and a half ${ }^{1}$ to ensure that enough is left to regenerate the soil [1]-[4]. In addition, a share of residues is attached to crops when they enter processing plants, most of which can also be collected.

Multiplying the tons of each crop in each country [5] by tons of harvest and processing residue per ton of crop [6], some 161 EJ of agricultural residue was generated worldwide in 2010. Taking $25 \%$ to $50 \%$ of harvest residue and $90 \%$ of processing residue, 55 to 90 EJ could have been used. With projected growth in food supply [7], assuming that the mix of crops is constant, available agricultural residue could reach 79 to $128 \mathrm{EJ}$ by $2050^{2}$.

However, much of this residue would likely be used for animal feed. Dividing the supply of meat between traditional grazing systems and higher-yield "mixed" systems in each country, and multiplying by the amount of residue used to produce each ton of meat, 19 EJ of residue is seen to have been used for feed in 2010. With projected growth in meat consumption [7], 33 EJ of residue could go to feed by 2050, leaving 46 to 95 EJ to use for biofuel $^{3}$. At a $40 \%$ conversion efficiency in a lignocellulosic process, this residue would yield 18 to $38 \mathrm{EJ}$ of biofuel. That is up to a third of all the liquid fuel that was used for transport in 2012, or nearly twice the amount of fuel used for marine shipping and aviation $[8]^{4}$.

\section{Potential for Bioenergy through Sustainable Intensification of Agriculture}

Growth in yields per hectare is responsible for some $80 \%$ of the increase in food production and residue potential implicit in FAO projections. Another $10 \%$ is due to planting multiple crops on the same land each year; only $10 \%$ of projected increased food production comes from expanding arable land [7]. But yields could grow faster if greater efforts were made to expand extension services that let farmers in countries with lower crop yields adopt the practices that produce higher yields elsewhere. With higher yields per hectare, less land would be needed for food and more could be used for biofuel feedstock.

FAO projects that global average major crop yield (excluding fruits and vegetables) will rise from $4.2 \mathrm{t} / \mathrm{ha}$ in 2010 to $5.1 \mathrm{t} /$ ha in 2050. But applying the regression trend in yield growth by crop from 1961 through 2013, the average could reach $6.6 \mathrm{t} / \mathrm{ha}$ in 2050 [5]. While $1079 \mathrm{M}$.ha would have to be planted in 2050 to meet world food needs at projected yields, just $839 \mathrm{M} \cdot \mathrm{ha}$ would be needed at the higher yields, freeing $240 \mathrm{M} \cdot \mathrm{ha}$ for biofuel crops.

Going further, FAO has assessed the gap between current and potential crop yields, assuming the current mix

\footnotetext{
${ }^{1}$ Reference [1] reports $75 \mathrm{~kg} / \mathrm{ha}$ of nitrogen fertilizer allows at least $25 \%$ of residues to be sustainably collected on half of Australian croplands, reaching $50 \%$ of residues in southeast Australia and $75 \%$ in southwest Australia. Reference [2] reports that removing $50 \%$ or $90 \%$ of residue with no-till planting reduces soil carbon and nitrogen by only $6 \%$ to $7 \%$. Reference [3] suggests 2.25 t/ha of residue can be removed for each crop under 2011 land management practices or $25 \%$ of $9.17 \mathrm{t} / \mathrm{ha}$ in total residue (weighting residue t/ha for each crop in table 5 by crop shares in table 7); table 6 shows no-till practices raise sustainable collection by $43 \%$, i.e. to $35 \%$, by 2030 . Reference [4] asserts that 50 of residue can be sustainably collected.

${ }^{2}$ Projected yearly growth in food supply is globally $1.3 \%$ through 2030 (ranging from $0.8 \%$ in developed countries to $2.4 \%$ in Sub-Saharan Africa) and $0.7 \%$ from 2030 through 2050 (ranging from $0.3 \%$ to $1.9 \%$ ).

${ }^{3}$ Projected annual growth in meat consumption is globally $1.4 \%$ through 2030 (from $0.6 \%$ in developed countries to $2.7 \%$ in Sub-Saharan Africa) and $0.9 \%$ from 2030 to 2050 (from $0.2 \%$ to $2.6 \%$ ).

${ }^{4}$ Data in [8] for 2012 indicate 2.17 EJ for domestic navigation, 7.91 EJ for marine bunkers, 4.12 EJ for domestic aviation, and 6.75 EJ for aviation bunkers, or a total of $21.95 \mathrm{EJ}$ for marine and aviation use.
} 
of irrigated and "rain-fed" land. Globally, the average gap is $62.1 \mathrm{t} / \mathrm{ha}$ for sugars, $3.9 \mathrm{t} / \mathrm{ha}$ for cereals, $12.7 \mathrm{t} / \mathrm{ha}$ for root crops, and $0.6 \mathrm{t} / \mathrm{ha}$ for oil crops [5]. Figure 1 illustrates the gap for maize, a leading cereal crop for biofuel production, in countries where it is grown; note that actual yield is less than $25 \%$ of potential yield for this crop in most of Africa and India and less than $40 \%$ in most of Latin America and Former Soviet Union.

For each country, taking the land to meet food demand with current yields for each crop type and dividing by the ratio of actual to potential yield, we calculated the land that would be required to meet food needs if the yield gap were closed. To close the gap would entail raising average global crop yield to $10.4 \mathrm{t} /$ ha in 2050 so that only $527 \mathrm{M} \cdot \mathrm{ha}$ would be needed for food, rather than the $1079 \mathrm{M} \cdot \mathrm{ha}$ projected by FAO, leaving $552 \mathrm{M} \cdot \mathrm{ha}$ for biofuel crops. If this land were planted with perennial grasses yielding $150 \mathrm{GJ} / \mathrm{ha}$, it could produce $83 \mathrm{EJ}$ of biomass. Converted at $40 \%$ efficiency, this would yield 33 EJ of biofuel, nearly a third of current transport fuel use.

\section{Potential for Bioenergy on Land Freed by Reducing Food Chain Waste and Losses}

Large amounts of food are lost in production and distribution, or wasted at the point of consumption. The FAO has found that one-third of food produced for human consumption is lost or wasted globally, amounting to 1.3 billion tons per year. Production and distribution losses have similar proportions in developed and developing countries, amounting to 31\% - 33\% in Europe and North America (280 - $300 \mathrm{~kg}$ out of $900 \mathrm{~kg}$ of food produced per capita per year) and 26\% - 37\% in sub-Saharan Africa and South/Southeast Asia (120 - $170 \mathrm{~kg}$ out of $460 \mathrm{~kg}$ of food produced per capita per year). But consumer food waste is much higher in developed countries (11\% 13\%) than developing ones (1\% - 2\%) [9].

For each major region and food group, FAO data show percentage losses in agricultural production, postharvest handling and storage, processing and packaging, retail distribution, and consumption [10]. From these, we calculated the total percentage and tonnage lost or wasted for each food group. Table 1 and Table 2 illustrate these for Europe and Sub-Saharan Africa, which are broadly representative of the pattern in developed and developing countries.

For crops directly consumed, we divided the tons lost or wasted by the average yield in tons per ha to calculate the number of ha that could be liberated by eliminating the losses and waste. For meat and dairy products, we first calculated the amounts of different kinds of feed to produce each, then the area used to produce the feed, and finally (multiplying this area by share of product lost) the land spared.

By this calculus, $442 \mathrm{M} \cdot$ ha of land could be freed up in 2050 by eliminating losses and waste for crops directly consumed as food, and another $340 \mathrm{M} \cdot \mathrm{ha}$ could be freed up by eliminating losses and waste of meat and dairy products. With $782 \mathrm{M}$.ha liberated in all, biofuel crops yielding $150 \mathrm{MJ} / \mathrm{ha}$ would provide $117 \mathrm{EJ}$ of biomass, converting at $40 \%$ efficiency to $47 \mathrm{EJ}$ of advanced biofuel. If the yield gap were closed, land freed by eliminating waste and losses would decline to $619 \mathrm{M} \cdot \mathrm{ha}$, biomass potential to $93 \mathrm{EJ}$ and biofuel potential to $37 \mathrm{EJ}$, still enough to displace a third of current liquid fuel use in transport. Table 3 shows the overall land that could theoretically be freed in this case by eliminating losses and waste at each stage, for each region and globally.

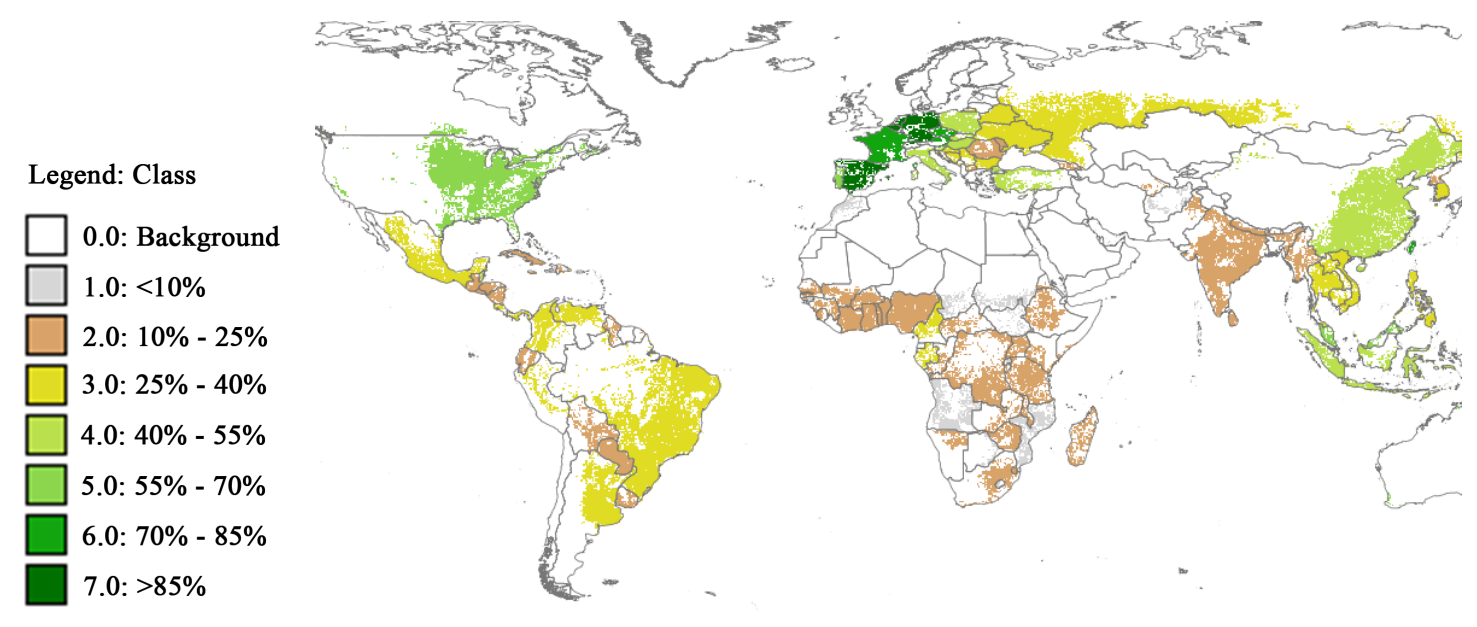

Figure 1. Ratio of actual to potential yield for Maize (Year 2000) [9]. 
Table 1. Shares of food production lost at different stages of the food chain in 2007 in Europe [10].

\begin{tabular}{|c|c|c|c|c|c|c|}
\hline Food Group & $\begin{array}{l}\text { Total Loss All } \\
\text { Combined }\end{array}$ & $\begin{array}{l}\text { Agricultural } \\
\text { Production }\end{array}$ & $\begin{array}{c}\text { Postharvest } \\
\text { Handling and Storage }\end{array}$ & $\begin{array}{l}\text { Processing and } \\
\text { Packaging }\end{array}$ & $\begin{array}{c}\text { Distribution: } \\
\text { Supermarket Retail }\end{array}$ & Consumption \\
\hline Cereals & $39 \%$ & $2 \%$ & $4 \%$ & $10 \%$ & $2 \%$ & $21 \%$ \\
\hline Roots \& Tubers & $65 \%$ & $25 \%$ & $9 \%$ & $14 \%$ & $5 \%$ & $12 \%$ \\
\hline Oilseeds, Pulses & $22 \%$ & $11 \%$ & $1 \%$ & $5 \%$ & $1 \%$ & $4 \%$ \\
\hline Fruit \& Vegetables & $57 \%$ & $25 \%$ & $5 \%$ & $2 \%$ & $9 \%$ & $16 \%$ \\
\hline Meat & $23 \%$ & $3 \%$ & $1 \%$ & $5 \%$ & $4 \%$ & $10 \%$ \\
\hline Fish \& Seafood & $35 \%$ & $10 \%$ & $1 \%$ & $6 \%$ & $8 \%$ & $9 \%$ \\
\hline Milk & $13 \%$ & $4 \%$ & $1 \%$ & $1 \%$ & $0 \%$ & $7 \%$ \\
\hline
\end{tabular}

Table 2. Shares of food production lost at different stages of the food chain in 2007in Sub-Saharan Africa [10].

\begin{tabular}{|c|c|c|c|c|c|c|}
\hline Food Group & $\begin{array}{c}\text { Total Loss All } \\
\text { Stages Combined }\end{array}$ & $\begin{array}{l}\text { Agricultural } \\
\text { Production }\end{array}$ & $\begin{array}{c}\text { Postharvest } \\
\text { Handling and Storage }\end{array}$ & $\begin{array}{l}\text { Processing and } \\
\text { Packaging }\end{array}$ & $\begin{array}{c}\text { Distribution: } \\
\text { Supermarket Retail }\end{array}$ & Consumption \\
\hline Cereals & $20 \%$ & $6 \%$ & $8 \%$ & $3 \%$ & $2 \%$ & $1 \%$ \\
\hline Roots \& Tubers & $51 \%$ & $16 \%$ & $18 \%$ & $12 \%$ & $3 \%$ & $1 \%$ \\
\hline Oilseeds \& Pulses & $32 \%$ & $14 \%$ & $8 \%$ & $7 \%$ & $2 \%$ & $1 \%$ \\
\hline Fruit \& Vegetables & $57 \%$ & $11 \%$ & $9 \%$ & $23 \%$ & $12 \%$ & $3 \%$ \\
\hline Meat & $32 \%$ & $18 \%$ & $1 \%$ & $5 \%$ & $7 \%$ & $2 \%$ \\
\hline Fish \& Seafood & $35 \%$ & $6 \%$ & $6 \%$ & $8 \%$ & $13 \%$ & $1 \%$ \\
\hline Milk & $26 \%$ & $6 \%$ & $11 \%$ & $0 \%$ & $9 \%$ & $0 \%$ \\
\hline
\end{tabular}

Table 3. Land freed by eliminating losses at different stages of the food chain by region (Million hectares).

\begin{tabular}{|c|c|c|c|c|c|c|}
\hline Region & $\begin{array}{l}\text { All Stages } \\
\text { Combined }\end{array}$ & $\begin{array}{l}\text { Agricultural } \\
\text { Production }\end{array}$ & $\begin{array}{l}\text { Postharvest Handling } \\
\text { and Storage }\end{array}$ & $\begin{array}{l}\text { Processing and } \\
\text { Packaging }\end{array}$ & $\begin{array}{c}\text { Distribution: } \\
\text { Supermarket Retail }\end{array}$ & Consumption \\
\hline Europe & 84 & 14 & 5 & 18 & 10 & 37 \\
\hline Africa & 81 & 32 & 12 & 18 & 14 & 6 \\
\hline Asia & 247 & 53 & 37 & 55 & 46 & 57 \\
\hline OECD Pacific & 24 & 4 & 1 & 6 & 4 & 10 \\
\hline North America & 74 & 14 & 3 & 16 & 8 & 33 \\
\hline South America & 108 & 29 & 9 & 26 & 20 & 23 \\
\hline World & 619 & 146 & 68 & 140 & 102 & 165 \\
\hline
\end{tabular}

\section{Energy Security Implications and Possible Policy Options}

The analysis indicates a potential for up to $270 \mathrm{EJ}$ of primary biomass from residues (95 EJ), land freed by closing the yield gap (82 EJ), and land freed by eliminating waste and losses in the food chain (93 EJ). This could provide up to $216 \mathrm{EJ}$ of useable bioenergy in a first generation biofuel conversion process or a conventional process for heat and electricity generation, or up to $108 \mathrm{EJ}$ of useable bioenergy in a second-generation conversion process to produce drop-in diesel fuel for jets, ships and trucks-roughly equivalent to the total amount of current liquid fuel use for transport worldwide in 2012. In view of the large potential, it is useful to consider what portion might practically be realized and what policies and measures would hold the most promise for developing the potential and bringing it to market.

Several courses of action could help to raise agricultural yields, which is key to raising supplies of residues 
and to freeing land for bioenergy crops. Capacity building and extension services could be expanded to spread modern farming techniques in developing countries. Best practices on logistical approaches for cost-effective harvesting of farm and forest residues could be compiled and disseminated. Agroforestry strategies for investing in cultivation of a mix of high-yielding food and fuel crops could be developed from successful experiences with stakeholders in different developing regions. Secure land tenure and effective land governance, in countries that do not have them, are essential to providing the financial incentives for long-term investment in intensive, sustainable land management.

A variety of policies and measures could also help to reduce food losses and waste. In developing countries, improved harvesting techniques, storage and cooling facilities and better packaging can reduce food spoilage, while expanded transportation infrastructure can bring more food to market while it remains fresh and saleable. Extension services and capacity building could help improve harvesting techniques, local health regulations could require better packaging, and development assistance could help build better infrastructure. In developed countries, waste can be reduced by differentiating prices to encourage sale of food items that are not perfect in shape or appearance, modifying labels so that "best-before" dates do not encourage consumers to discard food prematurely, and raising awareness of possible uses for safe food that is thrown away. Regulations to allow the sale of lower quality food items that meet health guidelines, engagement by food distributors and retailers to make food labels more informative and advertising to change consumers' attitudes can all play helpful roles [10].

\section{References}

[1] Zhao, G., Bryan, B.A., King, D., Luo, Z., Wang, E. and Yu, Q. (2014) Sustainable Limits to Crop Residue Harvest for Bioenergy: Maintaining Soil Carbon in Australia’s Agricultural Lands. GCB Bioenergy.

[2] Villamil, M.B. and Nafziger, E.D. (2015) Corn Residue, Tillage, and Nitrogen Rate Effects on Soil Carbon and Nutrient Stocks in Illinois. Geoderma, 253-254, 61-66. http://dx.doi.org/10.1016/j.geoderma.2015.04.002

[3] Muth Jr., D.J., Bryden, K.M. and Nelson, R.G. (2013) Sustainable Agricultural Residue Removal for Bioenergy: A Spatially Comprehensive US National Assessment. Applied Energy, 102, 403-417. http://dx.doi.org/10.1016/j.apenergy.2012.07.028

[4] World Bioenergy Association (2015) Global Bioenergy Statistics 2015. Stockholm.

[5] Food and Agricultural Organisation (2015) FAOSTAT. http://faostat3.fao.org

[6] Smeets, E., Faaij, A. and Lewandowki, I. (2004) A Quickscan of Global Bio-Energy Potentials to 2050. Utrecht University, Utrecht.

[7] Alexandratos, N. and Bruinsma, J. (2012) World Agriculture towards 2030/2050: The 2012 Revision. Food and Agricultural Organisation, Rome.

[8] International Energy Agency (2012) Energy Balances. Paris.

[9] FAO/IIASA (2011-2013) Global Agro-Ecological Zones (GAEZ v3.0). Rome and Laxenburg, Austria.

[10] Gustavsson, J., Cederberg, C., Sonesson, U., van Otterdijk, R. and Meybeck, A. (2011) Global Food Losses and Food Waste-Extent, Causes and Prevention. Food and Agricultural Organisation, Rome. 